\title{
Peran Partisipasi Masyarakat dalam Mewujudkan Kesejahteraan Anak melalui RW Ramah Anak
}

\author{
Lola Mulyantika ${ }^{1}$, Isbandi Rukminto Adi ${ }^{2}$ \\ ${ }^{1}$ Kementerian Desa, Pembangunan Daerah Tertinggal dan Transmigrasi \\ 2 Fakultas Ilmu Sosial dan Ilmu Politik, Universitas Indonesia \\ lola.mulyantika20@gmail.com adi1126@yahoo.com
}

\begin{abstract}
Abstrak: Artikel ini membahas mengenai peran partisipasi masyarakat dalam mewujudkan kesejahteraan anak melalui RW Ramah Anak. Metode yang digunakan dalam penelitian ini adalah metode kualitatif dengan pendekatan deskriptif. Hasil dari penelitian ini menunjukan bahwa partisipasi masyarakat mempunyai peran penting dalam mewujudkan kesejahteraan anak melalui RW Ramah Anak. Hal-hal yang mempengaruhi derajat partisipasi masyarakat adalah tingginya pemahaman masyarakat, motivasi internal untuk bergerak secara sukarela, modal komunitas dan agen pengubah. Dengan tingginya partisipasi masyarakat, program RW Ramah Anak bisa berjalan dengan baik, sehingga kesejahteraan anak terpenuhi ditandai dengan masalah anak dapat dikelola dengan baik, kebutuhan anak terpenuhi dan ada kesempatan anak untuk mengembangkan diri. Sebagai rekomendasi, pelaksanaan RW Ramah Anak perlu didukung secara anggaran oleh pemerintah, supaya pelaksanaannya lebih optimal lagi.
\end{abstract}

Kata Kunci: Partisipasi Masyarakat, Kesejahteraan Anak, RW Ramah Anak

Abstract: This article discusses the role of community participation in realizing child welfare through Child-Friendly in the neighborhood community $(R W)$. The method used in this research is a qualitative method with a descriptive approach. The results of this study indicate that community participation has an important role in realizing children's welfare through Child-Friendly $R W$. Things that affect the degree of community participation are the high level of public understanding, an internal motivation to move voluntarily, community capital, and agents of change. With high community participation, the Child-Friendly $R W$ program can run well, so that children's welfare is fulfilled, marked by children's problems can be managed properly, children's needs are met and there are opportunities for children to develop themselves. As a recommendation, the implementation of Child-Friendly $R W$ needs to be supported on a budget basis by the government, so that its implementation can be even more optimal.

Keyword: community participation, child welfare, child friendly city

\section{PENDAHULUAN}

Kesejahteraan anak merupakan suatu hal yang penting untuk dipenuhi, karena anak memberikan corak dan warna di masa mendatang. Kualitas suatu bangsa akan sangat tergantung dengan kualitas anak pada masa sekarang. Supaya anak bisa menjalankan fungsinya dengan baik, maka anak perlu dijaga, dibina dan ditingkatkan kualitas hidupnya. Memenuhi kondisi kesejahteraan pada anak dapat menyebabkan anak bisa tumbuh dan berkembang optimal sesuai dengan usianya serta anak mampu untuk menjadi generasi berkualitas yang memiliki potensi untuk membangun bangsa. Upaya untuk memenuhi kesejahteraan anak dapat dilakukan dengan memenuhi hak-hak anak. Di internasional, perlindungan terhadap hak-hak anak sudah diatur di dalam Konveksi Hak-hak Anak yang disetujui oleh Majelis Umum
Perserikatan Bangsa-bangsa pada tanggal 20 November 1989. Pasal 1 dalam konvensi ini menyebutkan bahwa anak adalah setiap orang yang berusia di bawah 18 tahun, kecuali ditentukan lain oleh hukum suatu negara. Selanjutnya, pasal 6 ayat (1) dan (2) dalam konvensi ini menyebutkan bahwa setiap negara mengakui bahwa tiap-tiap anak mempunyai hak yang melekat atas kehidupannya sehingga negara memiliki kewajiban untuk menjamin semaksimal mungkin ketahanan dan perkembangan anak. Pemerintah Indonesia sudah meratifikasi Konveksi Hak Anak melalui Keputusan Presiden Nomor 36 Tahun 1990 tentang pengesahan konvensi hak-hak anak, kewajiban untuk membuat langkah-langkah yang diperlukan bagi peningkatan kesejahteraan anak dan pemenuhan hak anak. 
Berdasarkan data dari dokumen Profil Anak tahun 2018 (Kemen PPA \& BPS, 2018) menyebutkan bahwa jumlah anak berusia 0-17 tahun di Indonesia pada tahun 2017 mencapai 79,6 juta jiwa atau sebesar 30,5 persen dari total penduduk. Perlindungan terhadap hak-hak anak ini memberikan arti penting karena kelompok penduduk usia muda mempunyai potensi untuk dikembangkan agar dapat berpartisipasi aktif dalam pembangungan untuk masa yang akan datang. Apalagi saat ini Indonesia sedang mengalami bonus demografi, sehingga penting untuk menyiapkan anak-anak yang berkualitas dan berdaya saing global, sehingga bonus demografi tidak sebagai ancaman namun sebagai peluang untuk kemajuan Indonesia.

Upaya untuk melindungi hak-hak anak dan kesejahteraan anak semakin nyata terwujud, dimana pada tahun 2011 Kementerian Pemberdayaan Perempuan dan Perlindungan Anak Republik Indonesia membentuk Permen PPPA No. 11 Tahun 2011 tentang Kebijakan Pengembangan Kabupaten/Kota Layak Anak atau disingkat dengan KLA. KLA adalah Kabupaten/Kota yang mempunyai sistem pembangunan berbasis hak anak melalui pengintegrasian komitmen dan sumberdaya pemerintah, masyarakat dan dunia usaha yang terencana secara menyeluruh dan berkelanjutan dalam kebijakan, program dan kegiatan untuk menjamin terpenuhinya hak anak.

Konsep KLA ini sejalan dengan upaya UNICEF sebagai penggagas Child Friendly City. Inisiatif ini diluncurkan pada tahun 1996 oleh UNICEF dan UN Habitat untuk bertindak berdasarkan resolusi yang disahkan selama Koferensi PBB tentang Pemukiman Manusia (Habitat II) untuk menjadikan kota-kota sebagai tempat tinggal yang layak bagi semua. Konferensi PBB menyatakan bahwa kesejahteraan anak adalah indikator utama dari tempat tinggal yang sehat, masyarakat yang demokratis dan pemerintah yang baik.

Child Friendly City yaitu setiap kota, komunitas atau sistem lain termasuk pemerintah lokal yang memiliki komitmen untuk meningkatkan kehidupan anak-anak sesuai dengan hukum dengan memenuhi hak-hak mereka sebagaimana tercantum di dalam Konvensi PBB tentang Hak-hak Anak. Secara praktiknya kebijakan ini menggambarkan bahwa sebuah kota atau komunitas dimana suara, kebutuhan, hak-hak anak merupakan merupakan bagian yang terintegrasi dengan kebijakan publik, pembuat program dan pengambil keputusan. Dalam konsep Child Friendly City menurut UNICEF (childfriendlycities.org, 2020), secara umum sebuah kota atau komunitas harus dapat memenuhi hak dan kebutuhan anak, sebagai berikut:

1. Dilindungi dari eksploitasi, kekerasan dan penyalahgunaan.

2. Memiliki awal kehidupan yang baik dan tumbuh sehat serta dirawat.

3. Memiliki akses ke layanan sosial yang berkualitas.

4. Pengalaman pendidikan yang berkualitas, inklusif dan partisipatif serta dapat mengembangkan keterampilan.

5. Mengekspresikan pendapat

6. Berpartisipasi dalam keluarga, budaya, kota/komunitas dan kehidupan sosial.

7. Hidup di lingkungan yang aman dan bersih dengan akses ke ruang hijau.

8. Bertemu dengan teman-teman dan memiliki tempat untuk bermain dan bersenang-senang

9. Memiliki kesempatan yang adil dalam hidup tanpa memandanga asal etnis, agama, pendapatan, jenis kelamin atau kemampuan mereka.

Tanggung jawab utama untuk memastikan hak-hak anak ini terwujud terletak pada pemerintah dan pemangku kepentingan lain seperti organisasi masyarakat sipil, sektor swasta, akademisi, media serta anak-anak itu sendiri juga memiliki peran penting untuk membangun Kota Ramah Anak.

Di Indonesia, dalam peraturan Menteri Negara Pemberdayaan Perempuan dan Perlindungan Anak RI Pasal 6 UU Nomor 11 tahun 2011 menyebutkan bahwa 
kebijakan pengembangan KLA diarahkan pada pemenuhan hak anak, meliputi:

1. Hak sipil dan kebebasan,

2. Lingkungan keluarga dan pengasuhan alternatif,

3. Kesehatan dasar dan pengasuhan alternatif,

4. Pendidikan, pemanfaatan waktu luang dan kegiatan budaya,

5. Perlindungan khusus.

Untuk mengefektifkan pengembangan KLA, dibentuk Gugus Tugas KLA yang keanggotaannya meliputi unsur-unsur lembaga terkait, perwakilan anak, dan dapat melibatkan dunia usaha dan masyarakat.

Putri (2013) menjabarkan bahwa pada awal pengembangan KLA, Provinsi Jawa Barat pada tahun 2010 menunjuk 5 Kabupaten/Kota untuk dijadikan pilot project KLA, yaitu Kabupaten Bogor, Kota Depok, Kabupaten Sukabumi, Kabupaten Sumedang, dan Kabupaten Karawang. Sebagai upaya tindak lanjut atas penunjukan Kota Depok sebagai pilot project KLA, Pemerintah Kota Depok sejak tahun 2010 sudah mulai melakukan tahapan persiapan menjadi Kota Layak Anak, dimulai dari acara sosialisasi yang diselenggarakan oleh Badan Pemberdayaan Perempuan dan Keluarga Berencana (BPPKB) Kota Depok, dilanjutkan dengan membuat Peraturan Daerah Kota Depok mengenai KLA yaitu Peraturan Daerah Nomor 15 Tahun 2013. Hingga sampai pada saat ini Kota Depok semakin komitmen untuk menjadi Kota Layak Anak. Dilansir dari (republika.co.id, 2019) Kota Depok mendapatkan penghargaan sebagai Kota Layak Anak dengan Predikat Nindya tiga tahun berturutturut, yaitu tahun 2017, 2018, dan 2019.

Menariknya, dalam implementai Kota Depok menuju Kota Layak Anak, penerapan program tidak hanya dilakukan secara top-down tetapi juga dilakukan dengan cara bottom-up, yakni pengembangan KLA dilakukan di tingkat RT/RW yang layak bagi anak, kemudian menuju ke Kelurahan Layak Anak,
Kecamatan Layak Anak dan Kota Layak Anak.

Dalam pelaksanaan RW Ramah Anak, diperlukan partisipasi masyarakat. Menurut Mikkelsen (Adi, 2013:228) menyebutkan bahwa partisipasi adalah keterlibatan masyarakat secara sukarela dalam perubahan yang ditentukan sendiri oleh masyarakat (participation is the voluntary involvement of people in selfdetermined change

Sejalan dengan itu, Adi (2013:231) menyimpulkan bahwa pada dasarnya partisipasi masyarakat adalah keikutsertaan masyarakat dalam proses pengidentifikasian masalah dan potensi yang ada di masyarakat, pemilihan dan pengambilan keputusan tentang alternatif solusi untuk menangani masalah, pelaksanaan upaya mengatasi masalah, dan keterlibatan masyarakat dalam proses mengevaluasi perubahan yang terjadi. Jadi, dapat dipahami bahwa partisipasi masyarakat adalah keterlibatan masyarakat secara sukarela dalam melakukan perubahan di masyarakat mulai dari identifikasi masalah dan potensi yang ada di masyarakat, pemilihan dan pengambilan keputusan terkait alternatif solusi untuk mengatasi masalah, pelaksanaan upaya mengatasi masalah dan evaluasi perubahan yang terjadi.

Dalam melaksanakan partisipasi masyarakat, maka tidak dapat dilepaskan dari modal yang ada di dalam komunitas. Menurut Adi (2013, h. 239-267) terdapat 7 modal komunitas, yaitu: 1. Modal fisik; 2. Modal finansial;, 3. Modal lingkungan; 4. Modal Teknologi; 5. Modal manusia; 6. Modal sosial; 7. Modal Spiritual. Ketujuh modal atau asset ini merupakan potensi yang dimiliki oleh masyarakat, kadangkala bisa menjadi kelebihan dari masyarakat ataupun sebaliknya bisa menjadi kelemahan dari masyarakat. Dalam penelitian ini, modal komunitas dilihat sebagai potensi yang dimiliki oleh masyarakat sehingga masyarakat mampu untuk berpartisipasi aktif dalam mengembangkan RW Ramah Anak. 
Selain itu, dalam mengembangkan RW Ramah Anak, peran dari agen pengubah yang ada di masyarakat juga penting, menurut Ife \& Tesoriero (2008, h. 665-669) agen pengubah bisa berasal dari internal dan eksternal masyarakat. Agen pengubah dari internal masyarakat berarti ia merupakan bagian dari masyarakat sementara agen pengubah eksternal adalah seseorang pekerja masyarakat yang datang dari tempat lain, yaitu (setidaknya pada awalnya) seseorang asing pada masyarakat dan terlihat sebagai 'orang luar'. Agen pengubah ini berperan dalam menjalankan berbagai macam keterampilan dalam melakukan perubahan di masyarakat, antara lain: peran dan keterampilan fasilitator, peran dan keterampilan pendidik, peran dan keterampilan perwakilan serta peran dan keterampilan teknis.

Sudah banyak penelitian yang membahas terkait dengan Kota Layak Anak, antara lain tentang proses pembentukan Kota Layak Anak, implementasi kebijakan dan program KLA, evaluasi pelaksanaan program KLA dan peran aktor dalam pelaksanaan KLA. Namun masih sedikit penelitian yang membahas terkait dengan RW Ramah Anak. Pada tahun 2016, Jeanne melakukan penelitian terkait dengan dinamika pelaksanaan RW Layak Anak di Kota Depok dengan membagi menjadi dua kasus. Kasus pertama adalah kelompok RW yang berhasil melaksanakan RW Layak Anak dengan partisipasi aktif masyarakat dan kasus ke-dua adalah kelompok RW dengan partisipasi masyarakat yang pasif sehingga tidak menimbulkan perubahan perilaku di masyarakatnya. Seiring berjalannya waktu dan perubahan dinamika yang terjadi di masyarakat. Penelitian terkait dengan partisipasi masyarakat dalam mendukung program RW Ramah Anak menjadi hal yang menarik untuk diteliti, karena sampai saat ini belum ada satupun kota di Indonesia yang dinobatkan menjadi Kota Layak Anak, kota-kota di Indonesia masih berjuang untuk mewujudkan kotanya menjadi Kota Layak Anak, sehingga peran partisipasi masyarakat perlu untuk ditingkatkan dalam mewujudkan visi ini.

Penelitian ini melanjutkan penelitian dari Jeanne pada tahun 2016 terkait dengam dinamikasi pelaksanaan RW Layak Anak dengan fokus melihat partisipasi masyarakat dalam pelaksanaan RW Ramah Anak. Penelitian ini dilakukan di RW 13 Kelurahan Cisalak, Kecamaran Sukmajaya, Kota Depok, Jawa Barat. RW 13 Kelurahan Cisalak merupakan salah satu RW di Kota Depok yang berhasil melaksanakan RW Ramah Anak. Pada tahun 2019 RW 13 berhasil mewakili Kelurahan Cisalak dalam mengikuti perlombaan Kelurahan Layak Anak di tingkat Kota Depok dan berhasil mendapat juara peringkat pertama. Hal ini bisa didapatkan, tidak lain karena peran partisipasi masyarakat di RW 13 dalam melaksanakan RW Ramah Anak di lingkungannya.

Berangkat dari rumusan masalah dan kesenjangan penelitian yang sudah dikemukakan di atas, maka penelitian ini memiliki tujuan untuk: 1) Mendeskripsikan dan menganalisis peran partisipasi masyarakat dalam mengembangkan RW Ramah Anak dan 2) mendeskripsikan dan menganalisis manfaat yang dirasakan oleh anak dengan adanya RW Ramah Anak.

\section{METODE PENELITIAN}

Berdasarkan latar belakang dan tujuan penelitian, maka pendekatan yang digunakan dalam penelitian ini adalah pendekatan kualitatif dengan metode deskriptif. Hal ini sejalan dengan yang dikatakan oleh Neuman (2006, h.149) bahwa pendekatan kualitatif lebih melihat kekayaan isu, tekstur dan perasaan dari data karena penelitian ini menggunakan pendekatan induktif dan menekankan pada pengembangan wawasan dan pengeneralisasian. Selanjutnya, Neuman (2006) juga mengatakan bahwa penelitian dengan metode deskriptif adalah penelitian yang tujuan utamanya adalah untuk menggambarkan dengan menggunakan katakata atau angka-angka dan untuk menyajikan 
sebuah profil, kualifikasi jenis, atau langkahlangkah secara garis besar untuk menjawab pertanyaan-pertanyaan siapa, kapan, dimana dan bagaimana.

Teknik pengumpulan data yang digunakan dalam penelitian ini adalah studi Pustaka/dokumentasi, wawancara dan observasi. Pengumpulan data dilakukan pada Bulan Oktober-November 2020 di RW 13 Kelurahan Cisalak, Kecamatan Sukmajaya, Kota Depok, Jawa Barat. Adapun kriteria informan dalam penelitian ini adalah pihakpihak yang mengetahui dan terlibat dalam program RW Ramah Anak di RW 13 Kelurahan Cisalak. Dalam hal ini pihak yang dimaksud adalah pengurus RW Ramah Anak, Ibu RW, anak-anak dan masyarakat umum di RW 13 Kelurahan Cisalak. Pihakpihak ini diharapkan mampu untuk memberikan informasi terkait dengan partisipasi masyarakat dalam RW Ramah Anak serta manfaat yang dirasakan oleh anak dengan adanya program RW Ramah Anak.

Teknik pengolahan data dalam penelitian ini menggunakan teknik pengolahan data yang dikemukakan oleh Ellen (Neuman, 2014, h.488). Sebelum dilakukan analisis, data mentah (data 1) yang didapat dari observasi lapangan, wawancara mendalam dan studi literatur diolah menjadi data 2, yaitu dengan membuat transkripnya terutrama dengan data berupa rekaman audio ditambah dengan catatan lapangan, setelah itu data yang ada dipilih, dilakukan klasifikasi data, kemudian dibuat pengkodean (coding) terhadap data yang ada sehingga menghasilkan data 3 , yaitu data yang dijadikan temuan lapangan untuk kemudian dianalisis sesuai dengan teori yang digunakan dalam penelitian ini.

\section{HASIL DAN PEMBAHASAN}

\section{Hasil (Temuan Lapangan)}

\section{a. Peran Partisipasi Masyarakat dalam} Program RW Ramah Anak

RW 13 Kelurahan Cisalak, Kecamatan Sukmajaya, Kota Depok, Jawa Barat mendapatkan Surat Keputusan (SK) sebagai RW Ramah Anak pada tahun 2017 yang tertuang dalam Keputusan Lurah Cisalak Nomor 821.29/75/Kpts/2017. Dalam implementasi RW Ramah Anak di RW 13, partisipasi masyarakat mempunyai peran besar dalam keberhasilan berjalannya program, sehingga pada tahun 2019, RW 13 terpilih menjadi RW yang mewakili Kelurahan Cisalak untuk mengikuti perlombaan Kelurahan Layak Anak di tingkat Kota Depok, dan mendapatkan juara satu. Berikut akan dipaparkan hasil data lapangan terkait dengan peran partisipasi masyarakat dalam mengembangkan RW Ramah Anak di RW 13 Kelurahan Cisalak, Kecamatan Sukmajaya, Kota Depok, yaitu:

1. Mengedukasi Masyarakat tentang RW Ramah Anak

Pada awal pembentukan RW Ramah Anak di RW 13 Kelurahan Cisalak, langkah awal yang dilakukan adalah mengedukasi masyarakat terkait dengan RW Ramah Anak, baik itu untuk pengurus RW Ramah Anak, pengurus RW dan RT serta seluruh masyarakat RW 13. Edukasi ini tujuannya adalah supaya pengurus dan masyarakat memahami terkait dengan RW Ramah Anak, hak-hak anak dan bisa bergerak bersama untuk melaksanakan program RW Ramah Anak. Hal ini sesuai dengan yang diutarakan oleh BA pengurus RW Ramah Anak di RW 13 ,

"Waktu awalnya memang kita perlu banyak mengedukasi masyarakat, pas kami ditunjuk menjadi RW Ramah Anak, dari kepengurusan perlu diedukasi, bahwa RW Ramah Anak itu penting buat kita, apa saja hak-hak anak yang harus kita berikan, ternyata tidak hanya sekedar membuat akta lahir, tapi kenyamanan-kenyamanan yang juga harus kita berikan ke anak" (BA, Oktober 2020).

Awalnya ada masyarakat yang bertanyatanya kenapa perlu ramah anak? Akhirnya setelah pengurus menjelaskan kepada masyarakat terkait dengan manfaat dan tujuan dari ramah anak, masyarakatpun menjadi paham dengan tujuan dari 
pelaksanaan RW Ramah Anak serta menjadi peduli dan ikut mensukseskan program ini. "Alhamdulillah, setelah adanya edukasi, masyarakat di sekitar kita sudah peduli akan hak-hak anak. Kenapa dibilang peduli, contohnya ' $\mathrm{Bu}$ anak-anak sering main sampai jam segini', itu bentuk kepedulian ya, atau misalnya semenjak ada wifi anakanak sering nongkrong. ' $\mathrm{Bu}$, gimana caranya?' Itukan bentuk kepedulian mereka, care mereka, itu sih yang saya lihat" (BA, Oktober 2020).

2. Gotong Royong untuk Membiayai Program RW Ramah Anak

Setelah pemahaman warga terkait dengan RW Ramah Anak meningkat, muncul kepedulian dari warga untuk turut mensukseskan agenda RW Ramah Anak ini, dengan membantu terkait dengan pendanaan program. BN sebagai pengurus RW Ramah Anak mengatakan bahwa untuk menjalankan RW Ramah Anak kita tidak bisa terpaku dengan pendanaan dari pemerintah. Kalau hanya menunggu dari pemerintah program RW Ramah Anak ini akan tidak berjalan, tapi peran dari ibu-ibu atau tokoh masyarakat sangat penting untuk berjalannya program RW Ramah Anak, karena ini merupakan pekerjaan sosial.

"Kita tidak terpaku kepada pendanaan dari pemerintah, atau peran serta pemerintah, kalau kita hanya menunggu dari pemerintah ini tidak akan berjalan Ramah Anaknya, tapi karena memang peran dari ibu-ibu ataupun tokoh masyarakat disini, itu memang kita menyadari kalau ini adalah pekerjaan sosial, apapun yang kita lakukan sedikit banyak hasilnya akan berhimbas kepada kita sendiri" (BN, Oktober 2020).

Untuk membiayai program RW Ramah Anak di RW 13, masyarakat menyepakati membuat program kencleng untuk RW Ramah Anak. Kencleng ini diisi secara sukarela oleh warga setiap sebulan sekali saat ada pertemuan ditingkat RT. Hasil dari iuran warga melalui kencleng ini lumayan dapat membiayai program kegiatan untuk anak di RW 13. Pengurus RW Ramah Anak mengakatan bahwa walaupun hasil kencleng belum mencukupi untuk semua kegiatan RW Ramah Anak, namun minimal sudah ada dana untuk bisa melaksanakan kegiatan terkait anak.

"Yaudah Bu kita mengadakan kencleng di tingkat RT aja, kalau tingkat RW kemungkinan dapatnya sedikit, mendingan di tingkat RT, seperti itu. Kan ada 3 RT nih jadi dapatnya bisa lumayan, ya alhamdulillah karena ada kesepakatan begitu, akhirnya berjalan, dan dapatnya lumayan, kita setor ke RW ke kas, kalau lagi banyak sampai 300, kadang 200 kadang 150, iya alhamdulillah, walau belum mencukupi untuk semua kegiatan kita, ya minimal adalah untuk kegiatan apa yang bisa mendorong anak untuk datang, kadang anak suka dengan kuekue" (BA, Oktober 2020).

Hal senada juga disampaikan oleh BN selaku pengurus RW Ramah Anak di bidang pendidikan.

"Kita punya kenclengen, jadi setiap arisan pertemuan itu kita masukin, untuk keperluan RW Ramah Anak, itu setiap sebulan sekali kita buka, alhamdulillah, kalau ada kekurangan ada aja yang bantu. Lama-lama warga berempati, oh anak-anak bisa begini, bisa bikin kegiatan itu" (BN, Oktober 2020).

Selain itu, warga juga ikut membantu dalam pendanaan program yang dilaksanakan oleh remaja atau anak-anak di RW 13. Anak-anak di RW 13 juga ikut berperan aktif dalam melaksanakan berbagai program di lingkungan masyarakat, diantaranya adalah buka bersama dengan warga di RW 13 dan acara 17 Agustus. Dari penuturan salah seorang anak di RW 13, Rd mengatakan bahwa ketika Ramadan anakanak dan remaja di RW 13 melaksanakan program buka bersama dengan warga. $\mathrm{Rd}$ mengaku bahwa terkait dengan dana untuk penyelenggaraan program didapat dari sumbangan orang tua di RW 13. "Ada kak, kalau Ramadan biasanya kita buka bersama, dari remaja, pesertanya anak-anak muda yang satu RW, dana didapat dari bantuan orang tua" (Rd, Oktober 2020). Senada dengan $\mathrm{Rd}$, Nd yang merupakan anak RW 13 yang menjadi panitia dalam program 17 
Agustus di RW 13 juga mengatakan bahwa agenda 17 Agustus disini dilaksanakan selama 3 minggu di Bulan Agustus. Terkait pendanaan program, panitia door to door ke rumah warga di lingkungan RW 13 untuk meminta sumbangan dan $\mathrm{Nd}$ mengatakan bahwa sumbangan dari warga mencukupi untuk agenda 17 Agustus yang mereka selenggarakan. "Sumbangan dari warga mencukupi banget kak" (Nd, Oktober 2020). 3. Melaksanakan berbagai Program Kegiatan untuk Anak

Pengurus RW Ramah Anak dan masyarakat di RW 13 aktif melaksanakan berbagai program dan kegiatan terkait dengan anak, antara lain: pekan permainan edukatif dan tradisional, TPA, panahan, tari, sekolah sepak bola, belajar Bahasa Arab, dan aktivitas posyandu, namun selama masa pandemi ini kegiatannya berhenti dulu karena masyarakat belum bisa untuk melaksanakan agenda yang mengumpulkan banyak orang dan anak-anak sibuk dengan Pembelajaran Jarak Jauh (PJJ). Hal ini seperti yang diutarakan oleh BN selaku pengurus RW Ramah Anak.

"Lalu kegiatan yang rutin itu ada pengajian, sebelum pandemi kegiatan kita disini ada Bahasa Arab, TPA, panahan, tari, Sekolah Sepak Bola (SSB), kegiatan ekoprint, lagi banyak yang berkerbun dan berternak selama pandemi, tapi kalau anak-anak sampai saat ini masih sibuk dengan PJJ." (BN, Oktober 2020)

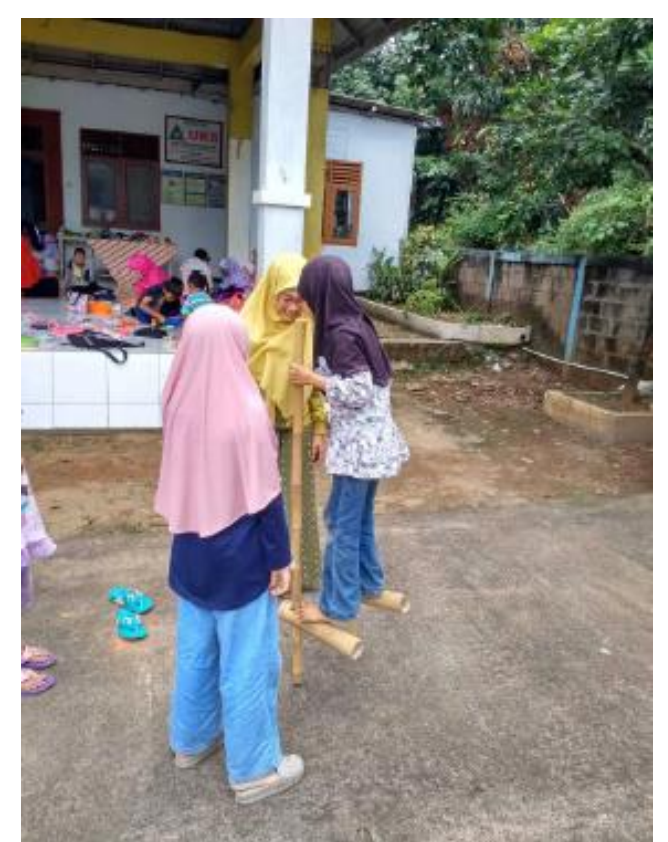

Gambar 1. Anak-anak Bermain Enggrang

(Sumber: Dokumentasi RW 13, 2020)

Gambar 1 merupakan kegiatan anak di RW 13 yang sedang mengikuti agenda pekan permainan edukatif dan tradisional. Terlihat di gambar anak-anak memainkan enggrang sebagai salah satu permainan tradisional yang dipandu oleh pengurus RW Ramah Anak di RW 13.

Selain kegiatan untuk anak, ada juga fasilitas yang disediakan untuk anak bisa belajar dan bermain yaitu taman bacaan yang berada di dalam Masjid RW 13 serta taman bermain di TK Bougenville RW 13. Anakanak di RW 13 dan di luar RW 13 bisa menggunakan fasilitas ini untuk belajar, membaca dan bermain.

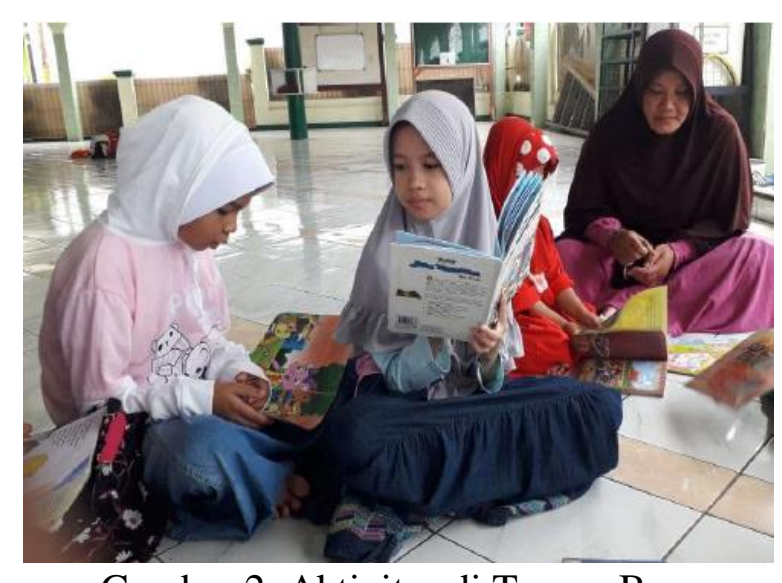

Gambar 2. Aktivitas di Taman Baca (Sumber: Dokumentasi RW 13, 2020) 


\section{Terakreditasi Peringkat 5 (No. SK: 85/M/KPT/2020)}

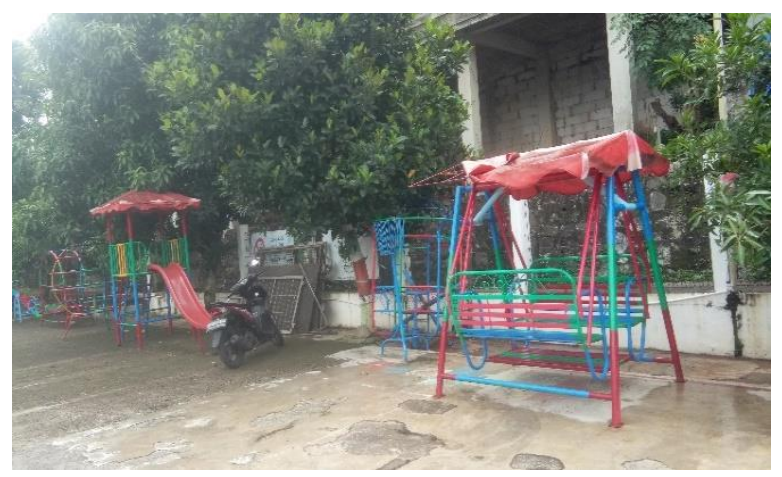

Gambar 3. Fasilitas Taman Bermain

(Sumber: Dokumentasi Penelitian, 2020)

Gambar 2 dan 3 menunjukan aktivitas belajar dan membaca bagi yang diikuti oleh anak-anak di RW 13, aktivitas membaca ini juga dipandu dan didampingi oleh pengurus RW Ramah Anak. Selanjutnya, gambar 3 menunjukan fasilitas bermain yang ada di RW 13, ada ayunan, perosotan dan besi panjat. Anak-anak didampingi orang tua biasanya bermain di taman bermain ini setiap sore hari. Namun selama pandemi anak-anak belum bisa untuk bermain di luar rumah.

Berikut tabel program kerja RW Ramah Anak di RW 13 sesuai dengan klaster yang ada pada RW Ramah Anak:

Tabel 1. Program Kerja RW Ramah Anak RW

\begin{tabular}{|l|l|l|}
\hline No. & \multicolumn{1}{|c|}{ Klaster } & \multicolumn{1}{c|}{ Kegiatan } \\
\hline 1. & $\begin{array}{l}\text { Hak sipil dan } \\
\text { kebebasan } \\
\text { (Klaster 1) }\end{array}$ & $\begin{array}{l}\text { a. Sosialisasi } \\
\text { pentingnya akta dan } \\
\text { KIA bagi anak } \\
\text { b. Membentuk Forum } \\
\text { Anak } \\
\text { c. Merealisasikan } \\
\text { papan informasi } \\
\text { layak anak }\end{array}$ \\
\hline 2. & $\begin{array}{l}\text { Lingkungan } \\
\text { Keluarga dan } \\
\text { Pengasuhan } \\
\text { Alternatif } \\
\text { (Klaster 2) }\end{array}$ & $\begin{array}{l}\text { Pelatihan dan } \\
\text { sosialisasi ketahanan } \\
\text { ketahanan keluarga } \\
\text { dan pengasuhan anak }\end{array}$ \\
\hline 3. & $\begin{array}{l}\text { Kesehaan } \\
\text { dasar dan } \\
\text { kesejahteraan }\end{array}$ & $\begin{array}{l}\text { a. Kampanye inisiasi } \\
\text { ASI eksklusif } \\
\text { b. Pendampingan }\end{array}$ \\
\hline
\end{tabular}

\begin{tabular}{|c|c|c|}
\hline & (Klaster 3) & $\begin{array}{l}\text { pemberian makanan } \\
\text { untuk gizi buruk } \\
\text { c. Melaksanakan } \\
\text { program imunisasi } \\
\text { d. Sosialisasi kepada } \\
\text { anak dan remaja } \\
\text { untuk tidak merokok } \\
\text { e. Menjadikan } 2 \text { titik } \\
\text { sentral: Pendopo } \\
\text { Bougenville dan } \\
\text { Masjid Al- } \\
\text { Mmuttaqien sebagai } \\
\text { Kawasan Tanpa } \\
\text { Rokok } \\
\text { e. Sosialisasi kepada } \\
\text { pemilik usaha untuk } \\
\text { tidak melayani } \\
\text { pembelian rokok } \\
\text { kepada anak }\end{array}$ \\
\hline No. & Klaster & Kegiatan \\
\hline 4. & $\begin{array}{l}\text { Pendidikan, } \\
\text { Pemanfaatan } \\
\text { Waktu Luang } \\
\text { dan Budaya } \\
\text { (Klaster 4) }\end{array}$ & $\begin{array}{l}\text { a. Pelatihan untuk } \\
\text { anak, agar terampil } \\
\text { minat dan bakatnya. } \\
\text { b. Memfasilitasi } \\
\text { pelatihan inovasi } \\
\text { yang lebih } \\
\text { mengedepankan } \\
\text { bahan daur ulang. } \\
\text { c. Meningkatkan } \\
\text { kualitas dan kuantitas } \\
\text { pelatihan seni, } \\
\text { budaya dan olahraga }\end{array}$ \\
\hline 5. & $\begin{array}{l}\text { Perlindungan } \\
\text { Khusus } \\
\text { (Klaster 5) }\end{array}$ & $\begin{array}{l}\text { a. Sosialisasi } \\
\text { pencegahan } \\
\text { kekerasan pada anak } \\
\text { b. Sosialisasi bahaya } \\
\text { NAPZA }\end{array}$ \\
\hline
\end{tabular}

Sumber: Buku Profil RW Ramah Anak RW 13 Kelurahan Cisalak, 2020)

Dalam melaksanakan program RW Ramah Anak ini, pengurus RW Ramah Anak di RW 13 Kelurahan Cisalak tidak menjalankannya sendiri, namun bekerja sama dengan berbagai struktur dan stakeholder yang ada di masyarakat, antara lain dengan: Pengurus RT, PKK, Pengurus Posyandu, IKRA013, Pos Paud Bougenville, 
Sanggar Tari Larasati, dan Club Sepakbola "34,5 FC". Kerjasama dan sinergi antar stakeholder di masyarakat ini menjadi kunci berjalannya program RW Ramah Anak di RW 13 Kelurahan Cisalak.

\section{b. Manfaat RW Ramah Anak bagi Anak}

Anak-anak merupakan target utama yang diharapkan merasakan manfaat dari pelaksanaan program RW Ramah Anak. Berikut dijabarkan temuan lapangan terkait dengan manfaat yang dirasakan oleh anak RW 13 Kelurahan Cisalak terkait dengan kegiatan RW Ramah Anak yang ada di lingkungan tempat tinggal mereka:

1. Anak-anak Mampu Bersosialisasi dengan Lingkungan Sekitar

Dengan berbagai kegiatan di RW Ramah Anak, Anak-anak di RW 13 Kelurahan Cisalak mampu bersosialisasi dan mengenal dengan baik teman-teman dan warga masyarakat di lingkungan RW 13. Seperti yang dituturkan oleh Rd, salah seorang anak di RW 13 "Mungkin kalau misalkan tidak ada RW Ramah Anak, mungkin orang-orang di rumah aja, kurang bergaul, dengan adanya RW Ramah Anak, ada acara-acara jadi kita bisa bertemu, ngumpul, Bahagia (Rd, Oktober 2020)

2. Anak-anak Sangat Kompak dan Saling Membantu

Anak-anak di RW 13 saling mengenal satu dengan yang lainnya dan terbentuk kekompakan diantara mereka, sehingga ketika ada anak yang membutuhkan bantuan, anak yang lain siap bersedia membantu.

"Satu hal misalnya seperti ini, ada diantara mereka yang sakit, teman-teman maaf ya aku nggak bisa menepati janji karena sakit, itu mereka share ke teman-temannya, lalu mereka balas, it's oke kita bisa melakukannya lain kali Mba, atau mereka jawab apa yang Mba butuhkan? Apa yang bisa kami bantu?, misalnya seperti itu, itu hal kecil dari karakter yang terbentuk." (BN, Oktober 2020).

BN pengurus RW Ramah Anak di RW 13 memaparkan bahwa, dengan kekompakan yang terbentuk di lingkungan anak-anak, mereka jadi memiliki rasa kepedulian yang tinggi dengan yang lainnya dan bersedia membantu jika dibutuhkan.

3. Anak-anak Mempunyai Tempat untuk Menyalurkan Hobi

$\mathrm{Rd}$ dan Ak yang merupakan anakanak di RW 13 Kelurahan Cisalak memapakar bahwa dengan adanya berbagai kegiatan untuk anak di lingkungan mereka, membuat mereka menjadi ada tempat untuk menyalurkan hobi dan bakatnya.

4. Anak-anak Merasa Nyaman di Lingkungan Masyarakat

BN selaku pengurus RW Ramah Anak mengatakan bahwa salah satu tujuan dari adanya RW Ramah Anak adalah anakanak merasa nyaman berada di dekat orang dewasa karena pendapat mereka dihargai dan diberlakukan secara baik oleh lingkungan. Kenyamanan tinggal di RW 13 dirasakan oleh anak-anak disini, hal ini sesuai dengan penuturan Rd, salah seorang anak di RW 13. "Iya nyaman tinggal disini dan bahagia kak, walau kelihatan tidak seperti itu, tapi kita guyup." (Rd, Oktober 2020).

5. Anak-anak Merasa Bahagia

Anak-anak merasa Bahagia karena banyak agenda dan permainan yang bisa mereka ikuti di lingkungan tempat tinggalnya.

"Kalau anak-anak yang sering kita ajak bermain tradisional ya, mereka happy, karena kita memperkenalkan lagi tentang permainan tradisional, kayak engklek, enggrang, congklak, ternyata mereka senang, mereka happy, sebelum pandemi permainan tradisional ini diadakan seminggu sekali, mereka senang, mereka happy, ada juga permainan karet, sampai mereka membuat karetnya sendiri." (BA, Oktober 2020).

Pernyataan dari BN selaku pengurus dibenarkan oleh $\mathrm{Rd}$, perwakilan anak RW 13, yang mengatakan bahwa permainan tradisional dibutuhkan oleh anak-anak saat sekarang, supaya anak-anak bisa mengenal permainan tradisional. "Seru ya, Kalau nggak ada permainan tradisional, mungkin 
kita tidak mengenal permainan tradisional, namun bagi saya sudah pernah merasakan waktu kecil, bagi anak-anak yang sekarang ini mungkin bisa jadi tidak tahu." (Rd, Oktober 2020).

\section{Dapat Mengurangi Kebiasaan Anak} Bermain Gadget

Berbagai program kegiatan untuk anak di RW 13 Kelurahan Cisalak, membuat mereka lebih aktif bergerak dan tidak terlalu bermain HP (Handphone). Namun BA menuturkan dimasa pandemi ini anak-anak kembali lekat dengan gadget dikarenakan pembelajaran dilakukan secara online. "Tidak terlalu main HP, menghindari terlalu banyak main gadget, karenakan ke luar rumah otomatis berpisah dengan HP nya, itu sebelum covid, sekarang setelah covid udah bermesraan lagi dengan HP, hehehe." (BA, Oktober 2020).

7. Anak-anak Lebih Dewasa dalam Menyelesaikan Masalah

Anak-anak di RW 13 Kelurahan Cisalak, belajar banyak hal positif dari lingkungan sekitarnya, mereka sudah bisa menyelesaikan masalah sendiri secara bijak, hal ini dituturkan oleh $\mathrm{BN}$ pengurus RW Ramah Anak.

"Ternyata mereka jika ada masalah mereka bisa menyelesaikan sendiri masalah mereka dengan bijak, itu akhirnya yang terbentuk, dari karakternya anak-anak, mereka itu tidak langsung berbicara kepada kita apa yang terjadi di lingkungan, tidak, mereka benarbenark keep, sampai akhirnya kita tahu, saya tahu dan cerita ke teman-teman yang lain, ya ternyata mereka itu hebat ya, mereka bisa menyelesaikan masalah mereka sendiri." (BN, Oktober 2020).

Sejalan dengan itu, Rd perwakilan dari anak menuturkan bahwa dengan pelibatan anakanak remaja untuk agenda anak-anak yang lebih kecil, mereka jadi belajar memahami bagaimana menghadapi anak-anak, walau diri mereka sendiri belum dewasa, "Kalau menurut saya, bagus untuk anak-anak, bagus untuk saya juga, karena ada acara Ramah Anak ini kita belajar juga untuk mengerti anak-anak, walau kita sendiri belum dewasa." (Rd, Oktober 2020)

8. Anak-anak Bisa Lebih Menghargai Orang Tua

An perwakilan dari anak RW 13 Kelurahan Cisalak menuturkan bahwa dengan adanya program RW Ramah Anak, anak-anak bisa belajar terkait dengan softskill berkomunikasi dengan orang yang lebih tua, awalnya dia meresa kesulitan untuk mejalin komunikasi dengan ibu-ibu yang ada di lingkungan rumahnya, namun karena sering melakukan kegiatan bersama, akhirnya An tahu bagaimana cara komunikasi ke orang tua dan juga ke anakanak yang lebih kecil darinya.

"Iya benar, benar-benar nambah softskill, kayak ngomong ke ibu-ibu aja awalnya susah, jadi kita belajar bagaimana cara komunikasi ke orang tua, ke anak-anak juga terus ya lumayan sih ya dari pada rebahan di rumah, karena kalau nggak dibikin acara pasti kita di rumah aja, seneng juga sih kan sekalian main ." (An, Oktober 2020)

9. Anak-anak Belajar untuk Bertanggungjawab

Program Kegiatan untuk anak-anak di RW 13 Kelurahan Cisalak tidak hanya dilakukan oleh pengurus tetapi juga dilakukan oleh anak-anak disini. Pelibatan anak-anak dengan program kegiatan RW Ramah Anak membuat mereka belajar untuk bertanggungjawab dalam menjalankan tugas yang diberikan. "Setiap kegiatan kita libatkan anak-anak dan mereka berhak untuk menyampaikan pendapat mereka. Di struktur organisasi kita ada nama anak-anak, mereka kita libatkan." (BN, Oktober 2020). Nd perwakilan dari anak mengatakan bahwa pelibatan anak-anak di program RW Ramah Anak ini juga baik untuk regenerasi, ia menuturkan bahwa tidak mungkin orang tua terus yang akan menjalankan program jadi anak-anaklah yang akan melanjutkan kegiatan-kegiatan yang sudah dilakukan oleh orang tua. "Iya sama, kayak lebih kenal, banyak belajar, di lingkungan bermasyarakat kayak gimana, terus habis itu lebih aktif juga gitu, soalnya kita kalau orang tua terus pasti 
akan selesai, jadi kita yang akan melanjutkan kegiatan-kegiatan yang orang tua sudah lakukan." (Nd, Oktober 2020)

Berikut tabel mengenai data yang dihimpun dari observasi, wawancara dan studi dokumentasi para informan di RW Ramah Anak RW 13 Kelurahan Cisalak, Kecamatan Sukmaya, Kota Depok, Jawab Barat.

Tabel 2. Peran Partisipasi Masyarakat dan Manfaat RW Ramah Anak bagi Anak

\begin{tabular}{|c|c|}
\hline $\begin{array}{c}\text { Peran } \\
\text { Partisipasi } \\
\text { Masyarakat }\end{array}$ & $\begin{array}{c}\text { Manfaat RW Ramah } \\
\text { Anak bagi Anak }\end{array}$ \\
\hline $\begin{array}{l}\text { 1. Mengedukasi } \\
\text { Masyarakat } \\
\text { tentang RW } \\
\text { Ramah Anak }\end{array}$ & $\begin{array}{l}\text { 1. Anak-anak Mampu } \\
\text { Bersosialisasi dengan } \\
\text { Lingkungan Sekitar }\end{array}$ \\
\hline $\begin{array}{c}\text { Peran } \\
\text { Partisipasi } \\
\text { Masyarakat } \\
\end{array}$ & $\begin{array}{c}\text { Manfaat RW Ramah } \\
\text { Anak bagi Anak }\end{array}$ \\
\hline $\begin{array}{l}\text { 2. Gotong } \\
\text { Royong untuk } \\
\text { Membiayai } \\
\text { Program RW } \\
\text { Ramah Anak } \\
\text { 3. Melaksanakan } \\
\text { berbagai } \\
\text { Program } \\
\text { Kegiatan untuk } \\
\text { Anak }\end{array}$ & $\begin{array}{l}\text { 2. Anak-anak Sangat } \\
\text { Kompak dan Saling } \\
\text { Membantu } \\
\text { 3. Anak-anak } \\
\text { Mempunyai Tempat } \\
\text { untuk Menyalurkan } \\
\text { Hobi } \\
\text { 4. Anak-anak Merasa } \\
\text { Nyaman di } \\
\text { Lingkungan } \\
\text { Masyarakat } \\
\text { 5. Anak-anak Merasa } \\
\text { Bahagia } \\
\text { 6. Dapat Mengurangi } \\
\text { Kebiasaan Anak } \\
\text { Bermain Gadget } \\
\text { 7. Anak-anak Lebih } \\
\text { Dewasa dalam } \\
\text { Menyelesaikan } \\
\text { Masalah } \\
\text { 8. Anak-anak Bisa } \\
\text { Lebih Menghargai } \\
\text { Orang Tua } \\
\text { 9. Anak-anak Belajar }\end{array}$ \\
\hline
\end{tabular}

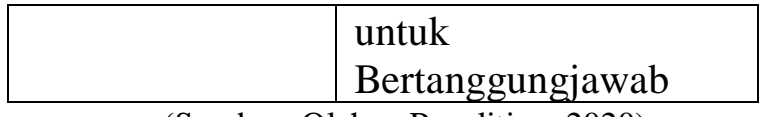

(Sumber: Olahan Penelitian, 2020)

\section{Pembahasan}

\section{a. Peran Partisipasi Masyarakat dalam Program RW Ramah Anak}

Program RW Ramah Anak merupakan bentuk implementasi kebijakan Kota Layak Anak secara bottom up, sesuai dalam penjelasan di BAB III lampiran Permen PPPA No. 11 Tahun 2011 tentang kebijakan KLA di Indonesia menyebutkan bahwa pendekatan bottom-up dalam KLA adalah pendekatan pengembangan KLA yang dimulai dari inisiatif individu/keluarga untuk kemudian dikembangkan di tingkat RT/RW yang layak bagi anak. Inisiatif masyarakat dalam sebuah wilayah RT/RW tersebut dapat dikembangkan ke RT/RW lainnya yang akhirnya menjadi sebuah gerakan masyarakat sebuah desa/kelurahan untuk mewujudkan "Desa/Kelurahan Layak Anak". Dari gerakan-gerakan masyarakat desa/kelurahan inilah dapat mendorong terwujudnya sebuah "Kecamatan Layak Anak". Akhirnya, kumpulan dari kecamatankecamatan layak anak tersebut dapat menjadi inisiatif kabupaten/kota yang bersangkutan untuk merealisasikan "Kabupaten/Kota Layak Anak". Dari penjabaran ini terlihat bahwa implementasi kebijakan KLA secara bottom up melalui program RW Ramah Anak, menuntut agar masyarakat bisa berpartisipasi secara aktif.

Masyarakat bisa berpartisipasi secara aktif jika masyarakat memahami terkait dengan program yang akan dilaksanakan. Oleh karena itu saat awal pembentukan RW Ramah Anak di RW 13 Kelurahan Cisalak Kecamatan Sukmajaya, langkah pertama yang dilakukan adalah mengedukasi pengurus dan masyarakat terkait dengan RW Ramah Anak, antara lain terkait dengan defisini RW Ramah Anak, visi, misi, tujuan program, peran yang bisa dilakukan oleh pengurus dan masyarakat, hak-hak anak serta manfaat pelaksanaan program.

Melalui edukasi ini, masyarakat bisa memahami terkait dengan program RW 
Ramah Anak, sehingga menimbulkan motivasi dari dalam diri masyarakat untuk bergerak bersama-sama secara sukarela dalam menyelenggarakan program kegiatan terkait dengan anak di lingkungan mereka. Hal ini sesuai dengan yang disampaikan oleh Mikkelsen (Adi, 2013:228) bahwa partisipasi masyarakat adalah keterlibatan masyarakat secara sukarela dalam perubahan yang ditentukan sendiri oleh masyarakat serta berasal dari masyarakat dan dikelola oleh masyarakat itu sendiri. Jadi, dapat dipahami bahwa semakin tinggi pemahaman masyarakat terkait dengan program ditambah dengan motivasi internal untuk bergerak secara sukarela maka semakin tinggi pula derajat partisipasi dari masyarakat.

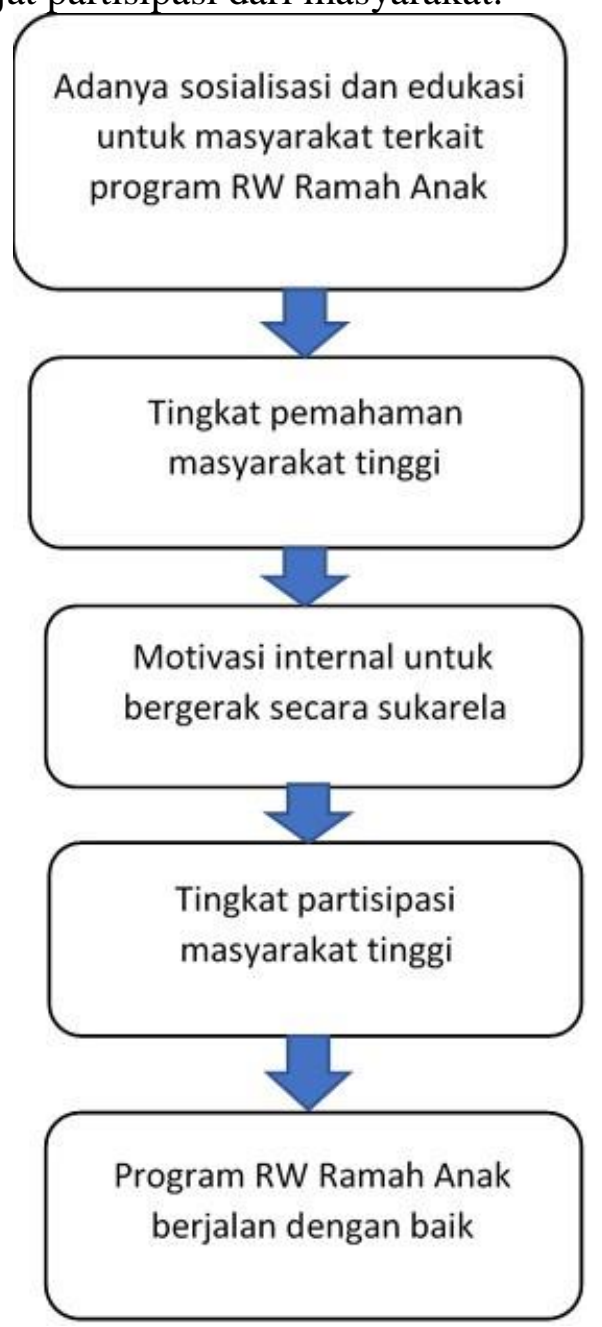

agan 1. Pemahaman dan Motivasi Partisipasi Masyarakat

(Sumber: olahan penelitian, 2020)
Partisipasi masyarakat bisa berjalan dengan baik, tidak terlepas dari modal yang dimiliki oleh masyarakat. Menurut Adi (2013, h.239-267), terdapat 7 aset atau modal yang dimiliki oleh masyarakat, yaitu: yaitu: 1. Modal fisik; 2. Modal finansial;, 3. Modal lingkungan; 4. Modal Teknologi; 5. Modal manusia; 6. Modal sosial; 7. Modal Spiritual. Ketujuh modal atau asset ini merupakan potensi yang dimiliki oleh masyarakat, kadangkala bisa menjadi kelebihan dari masyarakat ataupun sebaliknya bisa menjadi kelemahan dari masyarakat. Berikut gambaran modal komunitas RW Ramah Anak di RW 13 Kelurahan Cisalak, Kecamatan Sukmajaya.

Tabel 3. Modal Komunitas RW Ramah Anak (RW 13 Kel. Cisalak)

\begin{tabular}{|c|c|c|}
\hline No. & $\begin{array}{c}\text { Modal } \\
\text { Komunitas }\end{array}$ & $\begin{array}{c}\text { RW } 13 \text { Kel. Cisalak } \\
\text { Kec. Sukmajaya }\end{array}$ \\
\hline 1. & $\begin{array}{l}\text { Modal } \\
\text { Fisik }\end{array}$ & 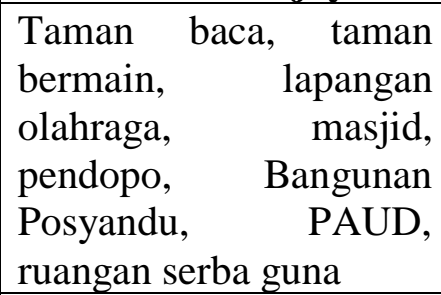 \\
\hline 2. & $\begin{array}{l}\text { odal } \\
\text { nansial }\end{array}$ & $\begin{array}{lr}\text { Iuran } & \text { swadaya } \\
\text { masyarakat } & \text { (kencleng } \\
\text { tiap RT) } & \end{array}$ \\
\hline 3. & $\begin{array}{l}\text { Modal } \\
\text { Lingkungan }\end{array}$ & $\begin{array}{l}\text { Tersedianya air bersih } \\
\text { dan udara bersih yang } \\
\text { memadai }\end{array}$ \\
\hline 4. & $\begin{array}{l}\text { Modal } \\
\text { Teknologi }\end{array}$ & $\begin{array}{l}\text { Website RW Ramah } \\
\text { Anak, Internet untuk } \\
\text { belajar anak }\end{array}$ \\
\hline 5. & $\begin{array}{l}\text { Modal } \\
\text { Manusia }\end{array}$ & $\begin{array}{l}\text { Pokja RW Ramah Anak, } \\
\text { Pengurus PKK, Karang } \\
\text { Taruna, Agen pengubah, } \\
\text { Guru Paud Bougenville }\end{array}$ \\
\hline 6. & $\begin{array}{l}\text { Modal } \\
\text { Sosial }\end{array}$ & $\begin{array}{l}\text { Warga masyarakat } \\
\text { kompak dan guyub serta } \\
\text { memiliki visi yang sama } \\
\text { untuk memenuhi hak } \\
\text { anak dan melaksanakan } \\
\text { kegiatan terkait anak. }\end{array}$ \\
\hline 7. & $\begin{array}{l}\text { Modal } \\
\text { Spiritual }\end{array}$ & $\begin{array}{l}\text { Adanya motivasi } \\
\text { internal untuk bergerak } \\
\text { bersama secara sukarela } \\
\text { dalam memenuhi hak }\end{array}$ \\
\hline
\end{tabular}




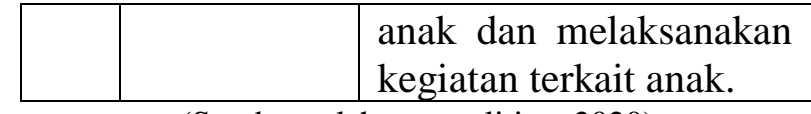

(Sumber: olahan penelitian, 2020)

Oleh karena itu, dalam penelitian ini kita bisa memahami variabel-variabel yang mempengaruhi tingkat partisipasi masyarakat, yaitu pemahaman masyarakat terkait dengan kebijakan atau program, motivasi internal untuk bergerak secara sukarela, modal komunitas dan adanya agen pengubah yang mengajak dan melibatkan masyarakat dalam perumusan kebijakan/program. Hubungan antara variabel-variabel ini dapat dilihat dalam bagan di bawah:

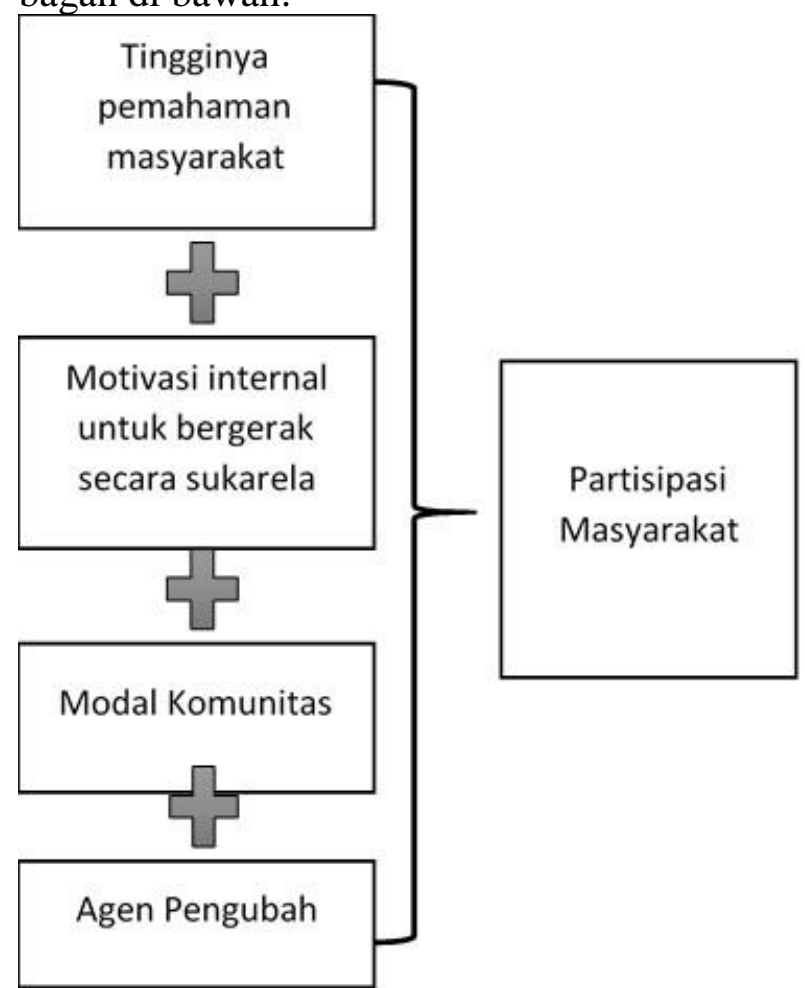

Bagan 2. Variabel yang Mempengaruhi Partisipasi Masyarakat

(Sumber: olahan penelitian, 2020)

\section{b. Manfaat RW Ramah Anak bagi Anak}

Anak merupakan target penerima manfaat utama dari pelaksanaan program RW Ramah Anak, yang dimaksud dengan anak sesuai dengan Pasal 1 Konveksi Hak Anak tahun 1989 menyebutkan bahwa anak adalah setiap orang yang berusia di bawah 18 tahun, kecuali ditentukan lain oleh hukum suatu negara. Anak merupakan aset berharga bagi bangsa dan negara, sehingga mewujudkan kesejahteraan anak menjadi hal penting yang harus dilakukan, untuk menyiapkan generasi penerus bangsa.

Midgley (2005, h.21) menyebutkan bahwa ada tiga elemen utama suatu kondisi disebut sejahtera, yaitu: pertama, suatu masalah sosial dapat dikelola dengan baik; kedua, kebutuhan masyarakat dapat dipenuhi; dan ketiga, tingkatan dimana kesempatan untuk mengembangkan diri disediakan ataupun difasilitasi oleh pemerintah. Dari pengertian di atas, maka dapat dipahami bahwa kesejahteraan anak adalah kondisi dimana masalah anak dapat dikelola dengan baik, kebutuhan anak terpenuhi dan anak mempunyai kesempatan untuk mengembangan diri.

Pelaksanaan program RW Ramah Anak di RW 13 Kelurahan Cisalak Kecamatan Sukmajaya, sudah memberikan berbagai macam manfaat bagi anak (lihat halaman 12-16), sehingga dapat dikatakan bahwa program RW Ramah Anak yang diwujudkan melalui partisipasi masyarakat mampu untuk meningkatkan kesejahteraan anak. Tabel berikut akan memaparkan terkait dengan kondisi kesejahteraan menurut Midgley dengan kondisi kesejahteraan anakanak di RW 13 Kelurahan Cisalak setelah dilakukan program RW Ramah Anak, sehingga dapat terlihat bahwa kondisi anakanak di RW 13 Kelurahan Cisalak sudah sejahtera, sesuai dengan defisini kondisi kesejahteraan sosial yang diutarakan oleh Midgley (2005, h.21).

Tabel 4. Kondisi Kesejahteraan Sosial menurut Midgley (2005) vs Kondisi Kesejahteraan Anak di RW 13 Kelurahan Cisalak

\begin{tabular}{|l|l|}
\hline $\begin{array}{c}\text { Kesejahteraan } \\
\text { Sosial (Midgley) }\end{array}$ & \multicolumn{1}{|c|}{$\begin{array}{c}\text { Kesejahteraan } \\
\text { Anak RW 13 Kel. } \\
\text { Cisalak }\end{array}$} \\
\hline $\begin{array}{l}\text { Masalah sosial dapat } \\
\text { dikelola dengan baik }\end{array}$ & $\begin{array}{l}\text { Masyarakat melalui } \\
\text { program RW Ramah } \\
\text { Anak berusaha untuk } \\
\text { mengelola dan } \\
\text { menyelesaikan } \\
\text { masalah yang ada } \\
\text { pada anak, dimana }\end{array}$ \\
\hline
\end{tabular}


Terakreditasi Peringkat 5 (No. SK: 85/M/KPT/2020)

\begin{tabular}{|c|c|}
\hline & $\begin{array}{l}\text { anak-anak } \\
\text { membutuhkan } \\
\text { pemanfaatan waktu } \\
\text { luang untuk kegiatan } \\
\text { positif dan } \\
\text { mengurangi gadget } \\
\text { ketergantungan } \\
\text { dengan sehingga dibuatlah } \\
\text { berbagai program } \\
\text { kegiatan untuk anak. }\end{array}$ \\
\hline $\begin{array}{l}\text { Kesejahteraan } \\
\text { Sosial (Midgley) }\end{array}$ & $\begin{array}{l}\text { Kesejahteraan } \\
\text { Anak RW } 13 \text { Kel. } \\
\text { Cisalak }\end{array}$ \\
\hline $\begin{array}{l}\text { Masalah sosial dapat } \\
\text { dikelola dengan baik }\end{array}$ & $\begin{array}{l}\text { Masyarakat melalui } \\
\text { program RW Ramah } \\
\text { Anak berusaha untuk } \\
\text { mengelola dan } \\
\text { menyelesaikan } \\
\text { masalah yang ada } \\
\text { pada anak, dimana } \\
\text { anak-anak } \\
\text { membutuhkan } \\
\text { pemanfaatan waktu } \\
\text { luang untuk kegiatan } \\
\text { positif dan } \\
\text { mengurangi } \\
\text { ketergantungan } \\
\text { dengan gadget } \\
\text { sehingga dibuatlah } \\
\text { berbagai program } \\
\text { kegiatan untuk anak. }\end{array}$ \\
\hline $\begin{array}{lr}\text { Ada kesempatan } \\
\text { untuk } \\
\text { mengembangkan diri } \\
\text { disediakan } \\
\text { difasilitasi } & \text { atau } \\
\text { pemerintah } & \text { oleh }\end{array}$ & $\begin{array}{l}\text { Dengan pelaksanaan } \\
\text { berbagai kegiatan } \\
\text { untuk anak di RW } 13 \\
\text { baik yang } \\
\text { dilaksanakan oleh } \\
\text { pengurus maupun } \\
\text { oleh anak itu sendiri, } \\
\text { anak mempunyai } \\
\text { kesempatan untuk } \\
\text { mengembangkan diri } \\
\text { dengan baik. }\end{array}$ \\
\hline
\end{tabular}

(Sumber: olahan penelitian, 2020)

\section{KESIMPULAN}

Penelitian yang berjudul Peran Partisipasi Masyarakat dalam Meningkatkan
Kesejahteran Anak melalui Program RW Ramah Anak ini, memiliki tujuan untuk mendeskripsikan dan menganalisis peran partisipasi masyarakat dalam mengembangkan program RW Ramah Anak dan manfaat RW Ramah Anak bagi anak. Beradasarkan pertanyaan penelitian dan tujuan penelitian pada pernyataan pertama yaitu untuk mendeskripsikan dan menganalisis peran partisipasi masyarakat dalam mengembangan RW Ramah Anak, maka terdapat beberapa fakta sebagai berikut:

1. Peran yang dilakukan masyarakat dalam mengembangkan RW Ramah Anak, antara lain:

a. Mengedukasi masyarakat tentang RW Ramah Anak

b. Gotong Royong untuk membiayai program RW Ramah Anak

c. Melaksanakan berbagai program kegiatan untuk anak

2. Terdapat modal komunitas yang medukung untuk pelaksanaan program RW Ramah Anak, yaitu: modal fisik, modal finansial, modal lingkungan, modal teknologi, modal manusia, modal sosial dan modal spiritual.

Dari fakta di atas dapat disimpulkan bahwa partisipasi masyarakat bisa terlaksana dengan baik karena adanya sosialisasi dan edukasi untuk masyarakat terkait dengan program RW Ramah Anak sehingga masyarakat mempunyai pemahaman yang tinggi terkait dengan program, adanya motivasi internal dari masyarakat untuk bergerak secara sukarela ditambah dengan modal komunitas yang dimiliki masyarakat dan agen pengubah yang mampu menggerakan masyarakat untuk bergerak.

Berdasarkan pertanyaan dan tujuan penelitian pada pernyataan kedua yaitu mendeskripsikan dan menganalisis manfaat yang dirasakan oleh ana dengan adanya program RW Ramah Anak, maka didapatkan fakta bahwa banyak manfaat yang dirasakan oleh anak dengan adanya RW Ramah Anak, antara lain: anak-anak mampu bersosialisasi dengan baik dengan lingkungan; sangat 
kompak dan saling membantu, anak-anak mempunyai tempat untuk mengalurkan hobi, merasa nyaman, bahagia, mampu mengurangi kebiasaan bermain gadget pada anak, mampu menyelesaikan masalah sendiri, mampu lebih menghargai orang tua dan anak-anak berlajar bertanggung jawab. Dari fakta tersebut dapat disimpulkan bahwa, berdasarkan dengan konsep Kesejahteraan menurut Midgley, dengan adanya RW Ramah Anak, kesejahteraan anak terpenuhi ditandai dengan masalah anak dapat dikelola dengan baik, kebutuhan anak terpenuhi dan ada kesempatakan anak untuk mengembangkan diri.

\section{E. SARAN}

Dalam rangka meningkatkan peran partisipasi masyarakat dalam meningkatkan kesejahteraan anak melalui RW Ramah Anak, maka ada beberapa rekomendasi sebagai berikut:

1. Dalam hasil lapangan ditemukan fakta bahwa, untuk mejalankan program RW Ramah Anak, sumber biaya program didapatkan dari iuran warga, oleh karena itu diharapkan pemerintah bisa mempunyai peran lebih di dalam menyediakan anggaran untuk RW Ramah Anak, karena RW Ramah Anak merupakan tiang utama dalam implementasi kebijakan Kota Layak Anak secara bottom up. Dengan begitu, harapannya program RW Ramah Anak tidak hanya bisa dijalankan oleh warga masyarakat yang mampu untuk memberikan dukungan dana dari swadaya masyarakat, tetapi bisa dijalankan pula di lingkungan masyarakat dengan berbagai latar belakang kondisi ekonomi.

2. Sebelum pandemi di dapatkan fakta bahwa banyak program kegiatan yang dilakukan untuk anak, namun selama pandemi kegiatannya berhenti dulu dikarenakan belum bisa mengumpulkan agenda yang mengundang banyak orang. Oleh karena itu ada baiknya pengurus RW Ramah Anak, membuat program kegiatan anak yang bisa dilaksanakan secara online, sehingga waktu luang anak bisa diisi dengan kegiatan yang positif.

\section{DAFTAR PUSTAKA}

Adi, Isbandi Rukminto. 2013. Intervensi Komunitas dan Pengembangan Masyarakat sebagai Upaya Pemberdayaan Masyarakat. Jakarta: PT Rajagrafindo Persada.

Ife, Jim dan Tesoriero. 2008. Community

Development: Alternatif

Pengembangan Masyarakat di Era Globalisasi Edisi Bahasa

Indonesia. Jakarta: Pustaka Pelajar

Midgley, James. 2005. Pembangunan Sosial Perspektif Pembangunan dalam Kesejahteraan Sosial. Jakarta: Diperta Depag RI

Neuman, W. Lawrance. 2006. Social Research Methods: Qualitative and Quantitative Approaches Sixth Edition. United States of America: Pearson Education Limited

Neuman, W. Lawrance. 2014. Social Research Methods: Qualitative and Quantitative Approaches Seventh Edition. United States of America: Pearson Education Limited

Putri, Ika Narwidya. 2013. Skripsi. Keswadayaan Masyarakat dalam Pengembangan RW Layak Anak di Kota Depok (Studi pada Masyarakat RW 06, Kelurahan Tanah Baru, Kecamatan Beji, Kota Depok). FISIP UI.

Tedja, Jeanne Noveline. 2016. Disertasi. Penyelenggaraan Kebijakan Kota Layak Anak di Kota Depok. FISIP UI.

Tedja, Jeanne Noveline. 2020. Partisipasi Masyarakat sebagai Modal Utama dalam Perubahan Perilaku di Lingkungan RW Layak Anak. Jurnal Karya untuk Masyarakat, Vol. 1, No. 1.

Peraturan Menteri Pemberdayaan Perempuan dan Perlindungan Anak RI. 2011. Undang-undang No. 11 Tahun 2011 tentang Kebijakan 
Pengembangan Kabupaten/Kota

Layak Anak

Peraturan Daerah. 2013. Peraturan Daerah Kota Depok Nomor 15 Tahun 2013 tentang Penyelenggaraan Kota Layak Anak

Child Friendly Cities. What is a childfriendly city?

https://childfriendlycities.org/what-isa-child-friendly-city/ diakses 12 Maret 2020

Child Friendly Cities. Why build a childfriendly city?

https://childfriendlycities.org/why-

build-a-child-friendly-city/ diakses 12 Maret 2020

Child Friendly Cities. What is the Child Friendly Cities Initiative? https://childfriendlycities.org/what-isthe-child-friendly-cities-initiative/ diakses 12 Maret 2020

Nurdiansyah, Rusdy. 2019. Depok Pertahankan Penghargaan Kota Layak Anak Nindya. https://nasional.republika.co.id/berita/ pv5d2j438/depok-pertahankanpenghargaan-kota-layak-anak-nindya diakses 21 Februari 2020).

UNICEF. Konveksi Hak Anak: Versi Anakanak https://www.unicef.org/indonesia/id/k onvensi-hak-anak-versi-anak-anak diakses 12 Maret 2020

UN. UN Convention Right Child Text. https://www.unicef.org/sites/default/fi les/2019-04/UN-Convention-RightsChild-text.pdf diakses 12 Maret 2020 